\title{
Effects of Thymol and Carvacrol, Constituents of Thymus vulgaris L. Essential Oil, on the Inflammatory Response
}

\author{
Fernanda Carolina Fachini-Queiroz, ${ }^{1}$ Raquel Kummer, ${ }^{1}$ Camila Fernanda Estevão-Silva, ${ }^{1}$ \\ Maria Dalva de Barros Carvalho, ${ }^{2}$ Joice Maria Cunha, ${ }^{3}$ Renata Grespan, ${ }^{1}$ Ciomar Aparecida \\ Bersani-Amado, ${ }^{1}$ and Roberto Kenji Nakamura Cuman ${ }^{1}$
}

${ }^{1}$ Department of Pharmacology and Therapeutic, State University of Maringá, 870020-900 Maringá, PR, Brazil

${ }^{2}$ Department of Medicine, State University of Maringá, 870020-900 Maringá, PR, Brazil

${ }^{3}$ Department of Pharmacology, Federal University of Paraná, 80060-000 Curitiba, PR, Brazil

Correspondence should be addressed to Roberto Kenji Nakamura Cuman,rkncuman@uem.br

Received 9 February 2012; Accepted 7 May 2012

Academic Editor: Ke Ren

Copyright ( 2012 Fernanda Carolina Fachini-Queiroz et al. This is an open access article distributed under the Creative Commons Attribution License, which permits unrestricted use, distribution, and reproduction in any medium, provided the original work is properly cited.

\begin{abstract}
Thyme (Thymus vulgaris L., Lamiaceae) is an aromatic and medicinal plant that has been used in folk medicine, phytopharmaceutical preparations, food preservatives, and as an aromatic ingredient. The effect of Thymus vulgaris essential oil (TEO) and its isolated constituents thymol and cavacrol (CVL) were studied in the following experimental models: ear edema, carrageenaninduced pleurisy, and chemotaxis in vitro. In the pleurisy model, TEO, CVL, and thymol significantly inhibited inflammatory edema. However, only TEO and CVL inhibited leukocyte migration. In the in vitro chemotaxis experiment, CVL inhibited leukocyte migration, whereas thymol exerted a potent chemoattractant effect. In the ear edema model, CVL (10 mg/ear), applied topically, reduced edema formation, exerting a topical anti-inflammatory effect. Thymol did not reduce edema formation but rather presented an irritative response, probably dependent on histamine and prostanoid release. Our data suggest that the antiinflammatory effects of TEO and CVL are attributable to the inhibition of inflammatory edema and leukocyte migration.
\end{abstract}

\section{Introduction}

Thyme (Thymus vulgaris L., Lamiaceae), a small subshrub native to the western Mediterranean region of Europe, has a long history of use and is a chemically variable species [1]. In folk medicine, some Thymus spp. are used for their antihelminthic, expectorant, antiseptic, antispasmodic, antimicrobial, antifungal, antioxidative, antivirotic, carminative, sedative, and diaphoretic effects. They are usually administered by infusion or are used externally in baths to cure rheumatic and skin disease $[2,3]$. Reports indicate that the volatile oils of thyme are among the main essential oils used in the food industry and in cosmetics as preservatives and antioxidants [1].

Thymus vulgaris essential oil (TEO) is a mixture of monoterpenes. The main compounds of this oil are the natural terpenoid thymol and its phenol isomer carvacrol (CVL) $[4,5]$, which have antioxidative, antimicrobial, antitussive, expectorant, antispasmodic, and antibacterial effects [6-10]. Terpenoids, flavonoid aglycones, flavonoids glycosides, and phenolic acids were also found in Thymus spp. [11].

Several studies have been performed with plant extracts $[4,12,13]$, but few studies have evaluated the effects of TEO and its isolated constituents in the inflammatory response. In the present study, the effects of TEO and its isolated components thymol and CVL were studied in experimental models of ear edema, carrageenan-induced pleurisy, and chemotaxis in vitro.

\section{Materials and Methods}

\subsection{Plant Material and Isolation of the Essential Oil}

2.1.1. Plant Material. The fresh leaves of Thymus vulgaris $\mathrm{L}$. were collected from the Profa Irenice Silva Medicinal Plant Garden on the campus of the State University of Maringá, 
Paraná, Brazil. The leaves were identified and authenticated by botanist Maria Aparecida Sert. A voucher specimen was deposited in the Herbarium of the Department of Botany, State University of Maringá (no. 11329).

2.1.2. Isolation of the Essential Oil. The leaves of Thymus vulgaris were extracted by conventional steam distillation using a Clevenger-type apparatus for $2 \mathrm{~h}$. The obtained essential oil was dried over sodium sulphate and stored at $4^{\circ} \mathrm{C}$ in dark vials until tested. The yield of TEO was $1.76 \%$ $\mathrm{v} / \mathrm{w}$. Thymol and CVL were isolated from TEO as fractions of hydrodistillated oil.

\subsection{Analysis of the Essential Oil and Compound Identification}

2.2.1. Gas Chromatography-Mass Spectrometry. Gas chromatography (GC) was performed with a Thermo Electron Corporation Focus GC model under the following conditions: DB-5 capillary column $(30 \mathrm{~m} \times 0.32 \mathrm{~mm}$, and $0.50 \mathrm{~mm})$; column temperature, $60^{\circ} \mathrm{C}(1 \mathrm{~min})$ to $180^{\circ} \mathrm{C}$ at $3{ }^{\circ} \mathrm{C} / \mathrm{min}$; injector temperature, $220^{\circ} \mathrm{C}$; detector temperature, $220^{\circ} \mathrm{C}$; split ratio, $1: 10$; carrier gas, He; flow rate, $1.0 \mathrm{~mL} / \mathrm{min}$. The volume injected $(1 \mu \mathrm{L})$ was diluted in chloroform $(1: 10)$. The GC/mass spectrometry (MS) analysis was performed with a Quadrupole mass spectrometer (DSQ II model, Thermo Electron Corporation) that operated at $70 \mathrm{~V}$. The identification of the individual compounds was based on comparisons of their GC retention indices (RI) on an apolar column and comparisons with the mass spectra of authentic standards purchased from Sigma-Aldrich and literature data [14]. The retention indices (RI) were obtained with reference to $n$-alkane $\mathrm{C}_{7} \mathrm{H}_{16}-\mathrm{C}_{44} \mathrm{H}_{90}$ series (supelcoBellefonte USA, UK).

2.2.2. Nuclear Magnetic Resonance. The Nuclear Magnetic Resonance (NMR) was used to prove the chemical structure of the essential oil constituents identified by CG-MS. ${ }^{1} \mathrm{H}$ $(300.06 \mathrm{MHz})$ and ${ }^{13} \mathrm{C}$ nuclear magnetic resonance (NMR; $75.45 \mathrm{MHz}$ ) spectra were recorded in a deuterated chloroform $\left(\mathrm{CDCl}_{3}\right)$ solution using a Mercury-300BB spectrometer, with $\delta(\mathrm{ppm})$ and spectra referenced to $\mathrm{CDCl}_{3}(\delta 7.27$ for ${ }^{1} \mathrm{H}$ and $\delta 77.00$ for ${ }^{13} \mathrm{C}$ ) as the internal standard.

2.3. Animals. Male Wistar rats (weighing 180-220 g) and male Swiss mice (weighing 25-30 g) were provided by the Central Animal House of the State University of Maringá. The animals were housed at $22 \pm 2^{\circ} \mathrm{C}$ under a $12 \mathrm{~h} / 12 \mathrm{~h}$ light/dark cycle. Prior to the experiments, the animals were fasted overnight, with water provided ad libitum. The experimental protocols were approved by the Ethical Committee in Animal Experimentation of the State University of Maringá (CEAE/UEM 066/2010).

2.4. Bioassays for Cytotoxic Activity. The MTT (3-[4,5-dimethylthiazol-2-yl]-2,5-diphenyl-2H-tetrazolium bromide) assay is based on the mitochondrial enzyme reduction of tetrazolium dye that detects and determines cell viability. The leukocytes were obtained from the peritoneal cavity of mice
$4 \mathrm{~h}$ after zymosan injection ( $1 \mathrm{mg} /$ cavity, i.p.). Briefly, the cells $\left(5 \times 10^{5}\right.$ cells/well) were exposed to $\operatorname{CVL}(1,3,10,30$, and $90 \mu \mathrm{g} / \mathrm{mL}$ ), thymol $(1.5,15$, and $150 \mu \mathrm{g} / \mathrm{mL}$, dissolved in dimethyl sulfoxide [DMSO]), or TEO $(1,3,10,30$, and $90 \mu \mathrm{g} / \mathrm{mL}$ ) for $90 \mathrm{~min}$ at $37^{\circ} \mathrm{C}$ in $5 \% \mathrm{CO}_{2}$. A volume of $10 \mu \mathrm{L}$ of MTT $(5 \mathrm{mg} / \mathrm{mL}$; Sigma) was added to each well. After $2 \mathrm{~h}, 150 \mu \mathrm{L}$ of the supernatant was removed, and $100 \mu \mathrm{L}$ DMSO was added to each well. The cells were incubated at $25^{\circ} \mathrm{C}$ for an additional $10 \mathrm{~min}$, and absorbance was measured using a Biochrom Asys Expert plus microplate reader (Asys) at a wavelength of $540 \mathrm{~nm}$. The values of the blank wells were subtracted from each well of treated and control cells. The percentage of viability was determined by the following formula:

\%viable cells:

(Absorbance of the treated cells-Absorbance of the blank)/

(Absorbance of the control-Absorbance of the blank) $\times 100$.

2.5. Acute Toxicity Test. Fasted mice were orally treated with TEO. The doses progressively increased to determine the dose necessary to produce lethality in $50 \%$ of the animals (LD50). The mice were observed for 7 days following the treatments. Food and water were provided ad libitum throughout the experiment. The number of mice that died within the study period was noted for each group. The LD50 was calculated according to the literature [15]. An equivalent dose of vehicle was administered to the control group.

2.6. Carrageenan-Induced Pleurisy in Rats. This test was performed according to the technique described by Vinegar et al. [16]. The animals were orally pretreated with TEO $(250,500$, or $750 \mathrm{mg} / \mathrm{kg})$, CVL $(100,200$, or $400 \mathrm{mg} / \mathrm{kg})$, and thymol $(100,200$, or $400 \mathrm{mg} / \mathrm{kg})$. Indomethacin $(5 \mathrm{mg} / \mathrm{kg})$ and celecoxib $(10 \mathrm{mg} / \mathrm{kg})$ were used as standard drugs. Control rats received only water. One hour later, all of the animals, with the exception of the normal group, received an intrapleural injection of carrageenan $(200 \mu \mathrm{g} / \mathrm{animal})$. Four hours later, the animals were euthanized, and the pleural exudate was collected. The volume was determined, and the pleural cavity was washed with $2.0 \mathrm{~mL}$ phosphate-buffered saline (PBS) that contained EDTA. The exudate volume was measured, and a $50 \mu \mathrm{L}$ aliquot was used to determine the number of leukocytes in a Neubauer chamber. For total leukocyte count, red blood cells were lysed by adding Turk's solution. For differential cell counting, the fluid was centrifuged at 2500 rotations per minute for $10 \mathrm{~min}$. Exudate smears were prepared, dried, fixed, and stained with May-Grunwald-Giemsa. The numbers of mononuclear and polymorphonuclear leukocytes in the exudate were determined by optical microscopy, with 100 cells counted per slide. The results are expressed as mean \pm SEM.

2.7. In Vitro Chemotaxis. To evaluate the effects of CVL and thymol on chemotaxis, leukocytes were obtained from the peritoneal cavity of mice $4 \mathrm{~h}$ after zymozan injection 
( $1 \mathrm{mg} /$ cavity, i.p). The cell number was adjusted to $1 \times 10^{6}$ cells/mL in RPMI medium containing $0.1 \%$ bovine serum albumin (BSA). The chemotaxis assay was performed using a 48-well microchemotaxis plate (Neuro Probe), in which the chambers were separated by a polyvinylpyrrolidone-free polycarbonate membrane $(5 \mu \mathrm{m}$ pore size). The chemoattractants $N$-formyl methionyl leucyl phenylalanine (fMLP; $10^{-6} \mathrm{M}$ ) and leukotriene B4 (LTB4; $10^{-8} \mathrm{M}$ ) and a negative control (RPMI 1640) were placed in the lower chamber. A leukocyte suspension $\left(1 \times 10^{6}\right.$ cells $\left./ \mathrm{mL}\right)$ pretreated with thymol $(0.3,1,3,10,30$, or $90 \mu \mathrm{g} / \mathrm{mL})$ and CVL $(0.3,1$, $3,10,30$, or $90 \mu \mathrm{g} / \mathrm{mL}$ ) for $30 \mathrm{~min}$ was then placed in the upper chamber. The cells were allowed to migrate into the membrane for $1 \mathrm{~h}$ at $37^{\circ} \mathrm{C}$ in $5 \% \mathrm{CO}_{2}$. Following incubation, the membrane was washed in PBS, fixed in methanol, and stained with Instant Prov. The membrane area of each well was scored using light microscopy to count the intact cells present in five random fields. The results are expressed as the mean number of leukocytes per field and are representative of three separate experiments.

To evaluate the chemoattractant effect of thymol on leukocyte chemotaxis, thymol was tested at concentrations of $1.5,15$, and $150 \mu \mathrm{g} / \mathrm{mL}$. The cells were obtained from the peritoneal cavity as described above. Thymol or RPMI 1640 were placed in the lower chamber. The leukocyte suspension $\left(1 \times 10^{6}\right.$ cells $\left./ \mathrm{mL}\right)$ was placed in the upper chamber, and the chemotaxis assay was performed as described above.

2.8. Topical Ear Edema. Cutaneous inflammation was induced by the application of $5 \%$ croton oil $(10 \mu \mathrm{L})$ in acetone (vehicle) to the inner surface of the right ear in mice. The left ear received an equal volume of vehicle. CVL (10, 20, and $40 \mathrm{mg} /$ ear $)$, thymol (10 mg/ear), indomethacin $(0.5 \mathrm{mg} / \mathrm{ear})$, dexamethasone $(0.1 \mathrm{mg} / \mathrm{ear})$, and vehicle were topically applied to the right ear $1 \mathrm{~h}$ before croton oil application. Four hours after the inflammatory stimulation, the mice were sacrificed, and a plug $(7 \mathrm{~mm}$ diameter $)$ was removed from both the treated and untreated ears $(n=10)$. Edema was measured as the weight difference between the two plugs. The data are expressed as the mean \pm SEM weight of the ears.

Thymol as a topical irritative was also tested. Ten microliters of thymol was applied to the right ears of mice, and the left ears received an equal volume of vehicle (acetone). The animals were treated with indomethacin $(5 \mathrm{mg} / \mathrm{kg}$, orally) or promethazine $(5 \mathrm{mg} / \mathrm{kg}$, i.p.) $60 \mathrm{~min}$ before the thymol application. Croton oil was used as a positive control. Ear edema was determined 30, 60, 120, 180, and $240 \mathrm{~min}$ after the inflammatory stimulation and is expressed as the increase in ear thickness measured with an electronic micrometer (Digimess) before and after the induction of the inflammatory response. The micrometer was applied near to the tip of the ear just distal to the cartilaginous ridges, and the thickness was determined in micrometers. To minimize the variations caused by using this technique, a single investigator made the measurements throughout all of the experiments. The data are expressed as the mean \pm SEM ear measurements.

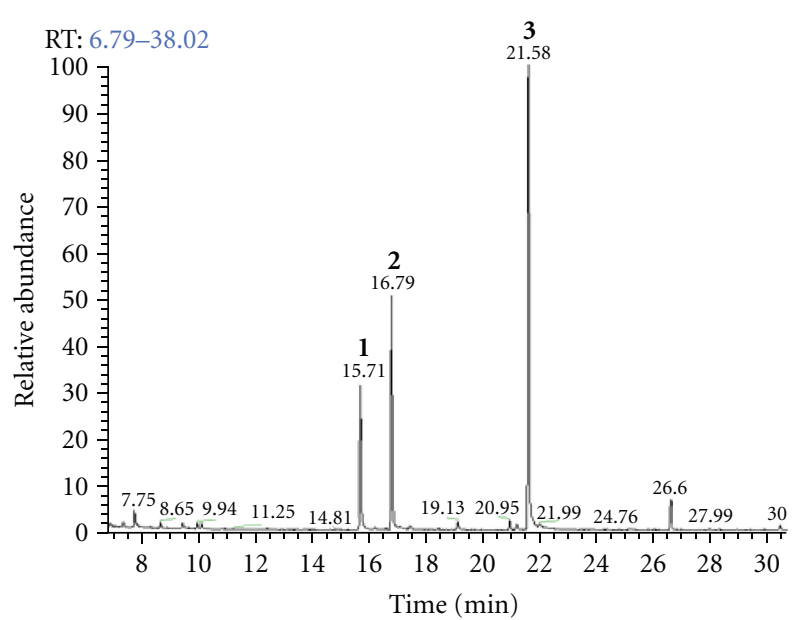

FIgURE 1: GC chromatogram of Thymus vulgaris L. essential oil. Percentage data were obtained by gas chromatography-mass spectrometry (GC-MS). Peak (1) endo-Borneol (14.3\%); (2) $\alpha$-Terpineol (22.9\%); (3) Carvacrol (45.5\%).

2.9. Myeloperoxidase Activity. Myeloperoxidase (MPO) activity was assayed in the supernatant of homogenates of the ear sections (untreated controls and animals treated with CVL, thymol, and $0.1 \mathrm{mg}$ dexamethasone) [17]. The ears were placed in $50 \mathrm{mM}$ potassium phosphate buffer $(\mathrm{pH}$ 6.0) that contained $0.5 \%$ hexadecyl trimethyl ammonium bromide ( $1 \mathrm{~mL} / 50 \mathrm{mg}$ of tissue; Sigma, St. Louis, MO, USA) in a Potter homogenizer. The homogenate was shaken in a vortex mixer and centrifuged for $5 \mathrm{~min}$. Ten microliters of the supernatant was added to each well in triplicate in a 96-well microplate. Two hundred microliters of the buffer solution that contained $16.7 \mathrm{mg} O$-dianisidine dihydrochloride (Sigma), $90 \mathrm{~mL}$ double-distilled water, $10 \mathrm{~mL}$ potassium phosphate buffer, and $50 \mu \mathrm{L}$ of $1 \% \mathrm{H}_{2} \mathrm{O}_{2}$ was added. The enzyme reaction was stopped by the addition of sodium acetate. Enzyme activity was determined by the absorbance measured at $460 \mathrm{~nm}$ using a microplate spectrophotometer (Spectra Max Plus).

2.10. Statistical Analysis. The data are expressed as the mean \pm SEM for each group. The data were statistically analyzed using one-way variance analysis followed by Tukey's test. Differences were considered significant at $P<0.05$.

\section{Results and Discussion}

The essential oils obtained from the leaves of Thymus are rich in monoterpene phenols, especially thymol and CVL [5]. The chemical composition of TEO was investigated using GCMS and NMR. The results of the GC-MS analysis (Figure 1) showed a predominance of CVL (45.5\%), $\alpha$-terpineol (22.9\%), and endo-Borneol (14.3\%). The percentages of the major components and their retention indices are summarized in Table 1.

In the cell viability assay, the treatments were tested at different concentrations. TEO at concentrations of $1,3,10$, 
TABle 1: Percentual chemical composition of Thymus vulgaris leaves essential oil.

\begin{tabular}{|c|c|c|c|c|}
\hline Retention time & Retention index ${ }^{\mathrm{a}}$ & Compound & Percentual (\%) & Identification \\
\hline 6.8 & 945 & Solvente & - & $\mathrm{MS}^{\mathrm{b}}$ \\
\hline 7.8 & 960 & $\alpha$-Pinene & 1.9 & MS, $\mathrm{NMR}^{\mathrm{d}}$ \\
\hline 8.7 & 1022 & p-Cymene & 0.6 & MS, NMR \\
\hline 9.9 & 1022 & Limonene & 0.6 & MS, NMR \\
\hline 10.1 & 1028 & $\gamma$-Terpinene & 1.1 & MS, NMR \\
\hline 11.3 & 1056 & Linalool & 0.2 & MS, NMR \\
\hline 14.8 & 1143 & Camphor & 0.1 & MS, NMR \\
\hline 15.7 & 1163 & endo-Borneol & 14.3 & MS, NMR \\
\hline 16.2 & 1175 & 4-Terpineol & 0.7 & MS, NMR \\
\hline 16.8 & 1187 & $\alpha$-Terpineol & 22.9 & MS, NMR \\
\hline 19.1 & $1240^{c}$ & Carvacrol methyl ether & 1.3 & MS, NMR \\
\hline 21.0 & $1289^{c}$ & Thymol & 0.9 & MS, NMR \\
\hline 21.6 & $1297^{c}$ & Carvacrol & 45.5 & MS, NMR \\
\hline 24.8 & 1417 & Geranyl acetate & 0.3 & MS, NMR \\
\hline 26.6 & 1417 & Caryophyllene & 3.2 & MS, NMR \\
\hline 30.8 & 1580 & Unknown & 0.8 & MS, NMR \\
\hline 33.2 & 1580 & Caryophyllene oxide & 2.9 & MS, NMR \\
\hline 35.3 & 1637 & Germacrene-D & 1.8 & MS, NMR \\
\hline 38.0 & 1708 & Unknown & 0.1 & MS, NMR \\
\hline
\end{tabular}

${ }^{\mathrm{a}} \mathrm{RI}$ : Retention index relative to a homologous series of $n$-alkanes on the DB- 5 capillary column.

${ }^{\mathrm{b}}$ Mass spectrometry.

${ }^{\mathrm{c}}$ Calculated considering retention time of 22.65 minutes.

${ }^{\mathrm{d}}$ Nuclear magnetic resonance.

30 , and $90 \mu \mathrm{g} / \mathrm{mL}$ showed cell viability of $88 \%, 82 \%, 90 \%$, $92 \%$, and $75 \%$, respectively. CVL at concentrations of 1,3 , 10,30 , and $90 \mu \mathrm{g} / \mathrm{mL}$ showed cell viability of $90 \%, 90 \%, 90 \%$, $88 \%$, and $87 \%$, respectively. Thymol at concentrations of 1.5 , 15 , and $150 \mu \mathrm{g} / \mathrm{mL}$ showed cell viability of $83 \%, 97 \%$, and $95 \%$, respectively. Our data indicated that TEO, CVL, and thymol did not present in vitro cytotoxicity at any of the concentrations tested.

In the acute toxicology study, TEO was tested orally at doses of $2000 \mathrm{mg} / \mathrm{kg}, 3000 \mathrm{mg} / \mathrm{kg}$, and $4000 \mathrm{mg} / \mathrm{kg}$. The LD50 value of TEO was $4000 \mathrm{mg} / \mathrm{kg}$. All of the doses used in the present study were lower than the observed LD50 values. Consequently, no apparent behavioral side effects were observed in the animals during our studies. The high LD50 values also suggest that TEO is relatively safe and nontoxic. Therefore, we studied the effects of TEO, CVL, and thymol on the inflammatory response evaluated by antiedematogenic activity and leukocyte migration.

Acute inflammation, typically characterized by redness, swelling, pain, and heat, is one of the most important defense mechanisms against invading pathogens. Lipopolysaccharide (LPS) can active monocytes, neutrophils, and macrophages [18] and induce an oversecretion of various proinflammatory and toxicity-mediating molecules, such as tumor necrosis factor $\alpha$ (TNF- $\alpha$ ), interleukin-6 (IL-6), eicosanoids, and nitric oxide (NO) [19]. Prostaglandins (PGs) and NO are two important proinflammatory mediators. The inhibition of the production of PGs and NO via the inhibition of their synthases (i.e., cyclooxygenase 2 [COX-2] and inducible nitric oxide synthase [iNOS], resp.) has been demonstrated to be beneficial in the treatment of inflammatory disease [20]. Anti-inflammatory drugs, such as steroids and nonsteroidal anti-inflammatory drugs (NSAIDs), have numerous adverse side effects, such as gastrointestinal discomfort, the inhibition of platelet aggregation, and liver and kidney toxicity [21]. Therefore, the search for natural products with fewer side effects has been increasingly important.

Different mechanisms are well known to be involved in the genesis of inflammatory reactions. The development of inflammatory edema induced by carrageenan is characterized by an initial stage (1-2 h) and is dependent on the release of histamine, serotonin, and bradykinin, followed by a later stage $(3-4 \mathrm{~h})$ that is maintained principally by the release of kinins, lysozymes, and prostanoids [22, 23]. Eicosanoids promote the chemotaxis of neutrophils, and they induce the biosynthesis of elastase, collagenase, and other compounds. These enzymes break down structural proteins into peptides. Consequently, vascular permeability and hydrostatic pressure increase, resulting in edema and the migration of neutrophils to the damaged tissue [24]. COX-2, an inducible enzyme found in activated inflammatory cells, plays a crucial role in cytokine production and prostanoid mediator release. The inhibition of COX-2 protein expression has been used to evaluate the anti-inflammatory effects of compounds in vivo and in vitro $[19,25,26]$. TNF- $\alpha$, a key mediator of the inflammatory response, stimulates innate immune responses 


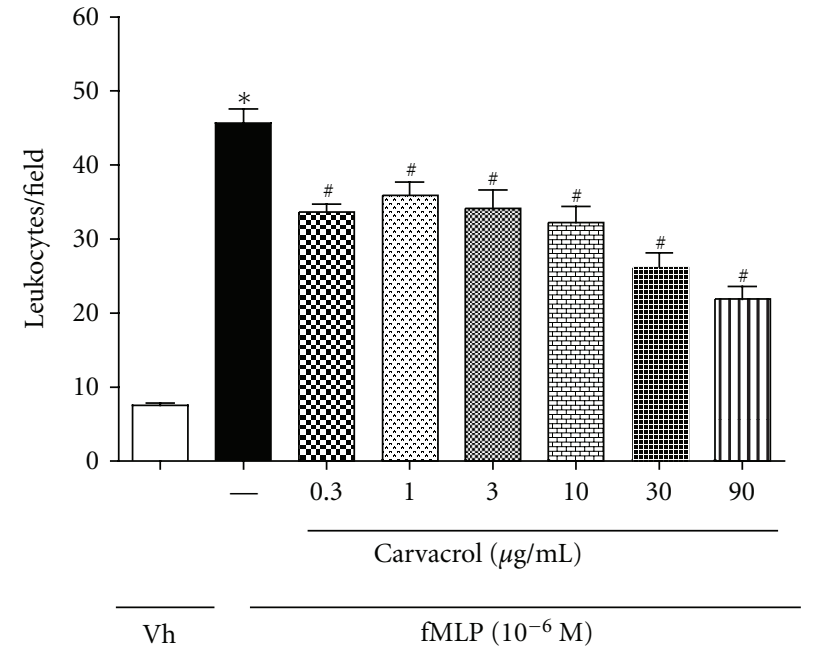

(a)

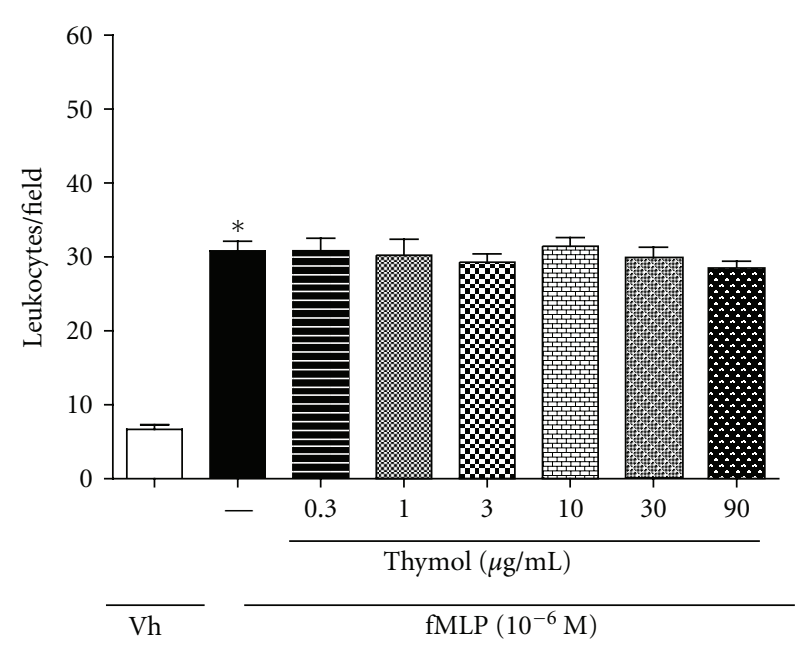

(c)

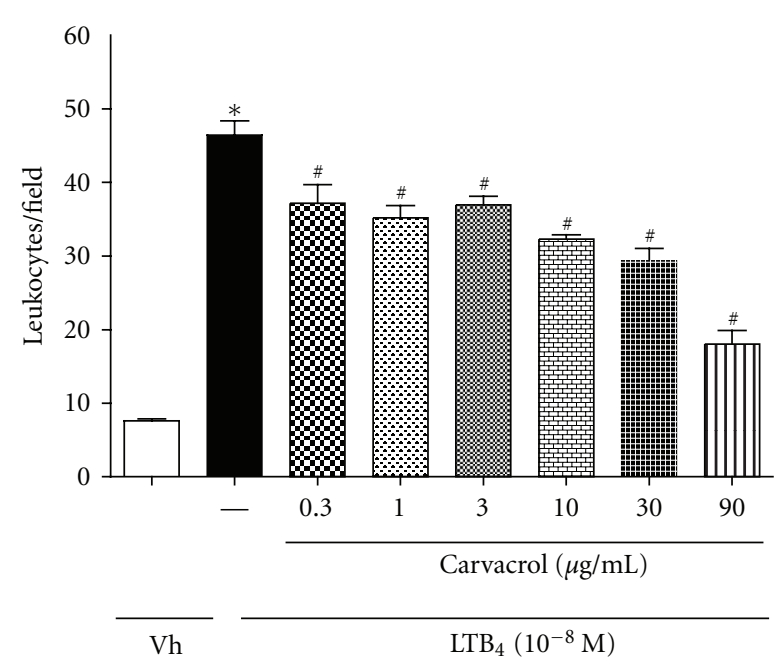

(b)

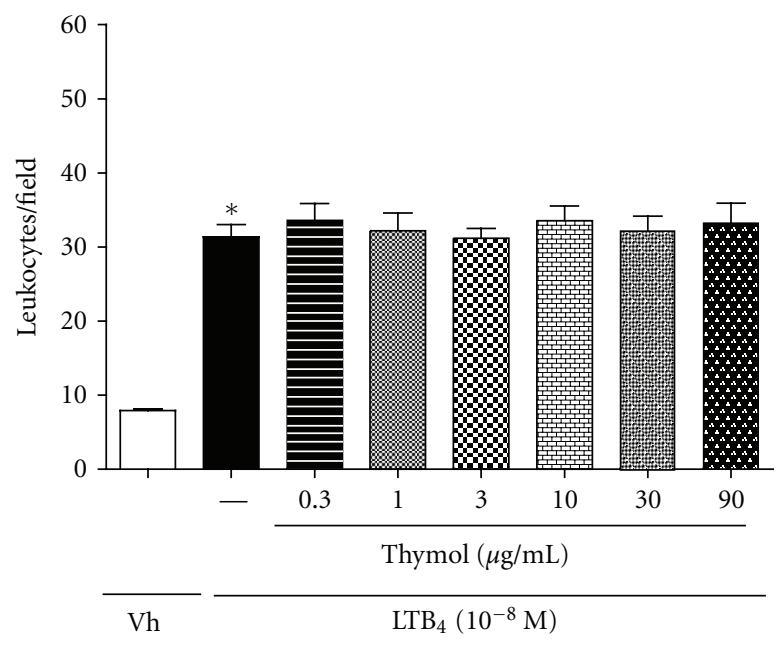

(d)

FIGURE 2: Effect of CVL and thymol on in vitro leukocyte chemotaxis. Leukocytes were obtained from zymosan-induced peritonitis $\left(200 \mu \mathrm{g} /\right.$ cavity) and stimulated with fMLP $\left(10^{-6}\right)$ or $\operatorname{LTB}_{4}\left(10^{-8}\right)$ after $30 \mathrm{~min}$ of CVL $(\mathrm{a}, \mathrm{b})$ or thymol (c, d) treatments at doses of 0.3 , $1,3,10,30$ and $90 \mu \mathrm{g} / \mathrm{mL}$. Values are mean $\pm \operatorname{SEM}(n=5)$ and are representative of three independent experiments. ${ }^{*} P<0.05$ versus Vh (vehicle), ${ }^{\#} P<0.05$ versus group of leukocytes stimulated with fMLP or $\mathrm{LTB}_{4}$.

TABLe 2: Effect of Thymus vulgaris essential oil (TEO) treatment on exudate volume and leukocytes number 4 hours after carrageenan injection $(200 \mu \mathrm{g} /$ pleural cavity) in rats.

\begin{tabular}{|c|c|c|c|c|c|}
\hline \multirow{2}{*}{ Group } & \multirow{2}{*}{ Exudate volume (mL) } & \multirow{2}{*}{ Inhibition (\%) } & \multicolumn{3}{|c|}{$\left(\right.$ cells $\left./ \mathrm{mm}^{3}\right) \times 10^{3}$} \\
\hline & & & Total leukocytes & $\mathrm{MN}$ & PMN \\
\hline Normal & $0.16 \pm 0.01$ & & $6700 \pm 450$ & $1800 \pm 160$ & $4900 \pm 390$ \\
\hline Control & $0.76 \pm 0.03^{b}$ & & $55650 \pm 1860^{\mathrm{b}}$ & $8831 \pm 644^{\mathrm{b}}$ & $46819 \pm 1399^{b}$ \\
\hline Indomethacin $(5 \mathrm{mg} / \mathrm{kg})$ & $0.33 \pm 0.02^{\mathrm{a}, \mathrm{b}}$ & 56.7 & $60250 \pm 7600^{\mathrm{b}}$ & $10162 \pm 1137^{\mathrm{b}}$ & $50088 \pm 6989^{b}$ \\
\hline Celecoxib $(10 \mathrm{mg} / \mathrm{kg})$ & $0.43 \pm 0.03^{\mathrm{a}, \mathrm{b}}$ & 43.3 & $42350 \pm 3536^{\mathrm{b}}$ & $6972 \pm 1047^{\mathrm{b}}$ & $35378 \pm 3774^{\mathrm{b}}$ \\
\hline \multicolumn{6}{|l|}{ TEO } \\
\hline $250 \mathrm{mg} / \mathrm{kg}$ & $0.62 \pm 0.02^{\mathrm{a}, \mathrm{b}}$ & 18.4 & $52696 \pm 2558^{\mathrm{b}}$ & $10786 \pm 1156^{\mathrm{b}}$ & $41910 \pm 2646^{\mathrm{b}}$ \\
\hline $500 \mathrm{mg} / \mathrm{kg}$ & $0.61 \pm 0.03^{\mathrm{a}, \mathrm{b}}$ & 19.7 & $54729 \pm 3090^{\mathrm{b}}$ & $7457 \pm 924.9^{\mathrm{b}}$ & $47272 \pm 2354^{\mathrm{b}}$ \\
\hline $750 \mathrm{mg} / \mathrm{kg}$ & $0.53 \pm 0.04^{\mathrm{a}, \mathrm{b}}$ & 30.2 & $41417 \pm 2125^{\mathrm{a}, \mathrm{b}}$ & $5873 \pm 415.7^{\mathrm{b}}$ & $35543 \pm 1801^{\mathrm{a}, \mathrm{b}}$ \\
\hline
\end{tabular}

Data are mean \pm SEM of 8-10 animals/group. Indomethacin and celecoxib administered orally were used as reference anti-inflammatory drugs (positive controls). Normal: animals that received injection of saline in the cavity (normal group), Control: animals that received injection of carrageenan in the cavity (negative control). MN: mononuclears cells. PMN: polimorphonuclears cells. ${ }^{\text {a }} P<0.05$ compared to control group; ${ }^{\text {b }} P<0.05$ compared to normal group (ANOVA, Tukey's test). 
TABLE 3: Effect of carvacrol treatment on exudate volume and leukocytes number 4 hours after carrageenan injection (200 $\mu \mathrm{g} / \mathrm{pleural}$ cavity) in rats.

\begin{tabular}{lccccc}
\hline Group & Exsudate volume $(\mathrm{mL})$ & Inhibition $(\%)$ & & \multicolumn{2}{c}{$\left(\right.$ cells $\left./ \mathrm{mm}^{3}\right) \times 10^{3}$} \\
& & & Total leukocytes & MN & PMN \\
\hline Normal & $0.16 \pm 0.01$ & $6700 \pm 450$ & $1800 \pm 160$ & $4900 \pm 390$ \\
Control & $0.76 \pm 0.03^{\mathrm{b}}$ & & $55650 \pm 1860^{\mathrm{b}}$ & $8831 \pm 644^{\mathrm{b}}$ & $46819 \pm 1399^{\mathrm{b}}$ \\
Indomethacin $(5 \mathrm{mg} / \mathrm{kg})$ & $0.33 \pm 0.02^{\mathrm{a}, \mathrm{b}}$ & 56.7 & $60250 \pm 7600^{\mathrm{b}}$ & $10162 \pm 1137^{\mathrm{b}}$ & $50088 \pm 6989^{\mathrm{b}}$ \\
Celecoxib $(10 \mathrm{mg} / \mathrm{kg})$ & $0.43 \pm 0.03^{\mathrm{a}, \mathrm{b}}$ & 43.3 & $42350 \pm 3536^{\mathrm{b}}$ & $6972 \pm 1047^{\mathrm{b}}$ & $35378 \pm 3774^{\mathrm{b}}$ \\
Carvacrol & & & & & \\
\multicolumn{1}{l}{$100 \mathrm{mg} / \mathrm{kg}$} & $0.68 \pm 0.01^{\mathrm{b}}$ & - & $32250 \pm 3256^{\mathrm{a}, \mathrm{b}}$ & $4522 \pm 635.3^{\mathrm{b}}$ & $27728 \pm 2696^{\mathrm{b}}$ \\
$200 \mathrm{mg} / \mathrm{kg}$ & $0.65 \pm 0.02^{\mathrm{b}}$ & - & $38625 \pm 2617^{\mathrm{a}, \mathrm{b}}$ & $5544 \pm 430.9^{\mathrm{b}}$ & $33081 \pm 2171^{\mathrm{b}}$ \\
$400 \mathrm{mg} / \mathrm{kg}$ & $0.40 \pm 0.05^{\mathrm{a}, \mathrm{b}}$ & 47.3 & $33583 \pm 2548^{\mathrm{a}, \mathrm{b}}$ & $4914 \pm 353.8^{\mathrm{b}}$ & $28669 \pm 2211^{\mathrm{a}, \mathrm{b}}$ \\
\hline
\end{tabular}

Data are mean \pm SEM of 8-10 animals/group. Indomethacin and celecoxib administered orally were used as reference anti-inflammatory drugs (positive controls). Normal: animals that received injection of saline in the cavity (normal group), Control: animals that received injection of carrageenan in the cavity (negative control). MN: mononuclears cells. PMN: polimorphonuclears cells. ${ }^{a} P<0.05$ compared to control group; ${ }^{b} P<0.05$ compared to normal group (ANOVA, Tukey's test).

TABLE 4: Effect of thymol treatment on exudate volume and leukocytes number 4 hours after carrageenan injection (200 $\mu \mathrm{g} / \mathrm{pleural}$ cavity) in rats.

\begin{tabular}{|c|c|c|c|c|c|}
\hline \multirow{2}{*}{ Group } & \multirow{2}{*}{ Exsudate volume (mL) } & \multirow{2}{*}{ Inhibition (\%) } & \multicolumn{3}{|c|}{$\left(\right.$ cells $\left./ \mathrm{mm}^{3}\right) \times 10^{3}$} \\
\hline & & & Total leukocytes & $\mathrm{MN}$ & PMN \\
\hline Normal & $0.16 \pm 0.01$ & & $6700 \pm 450$ & $1800 \pm 160$ & $4900 \pm 390$ \\
\hline Control & $0.76 \pm 0.03$ & & $55650 \pm 1860^{\mathrm{b}}$ & $8831 \pm 644^{\mathrm{b}}$ & $46819 \pm 1399^{b}$ \\
\hline Indomethacin $(5 \mathrm{mg} / \mathrm{kg})$ & $0.33 \pm 0.02^{\mathrm{a}}$ & 56.7 & $60250 \pm 7600^{b}$ & $10162 \pm 1137^{b}$ & $50088 \pm 6989^{b}$ \\
\hline Celecoxib (10 mg/kg) & $0.43 \pm 0.03^{\mathrm{a}}$ & 43.3 & $42350 \pm 3536^{\mathrm{b}}$ & $6972 \pm 1047^{\mathrm{b}}$ & $35378 \pm 3774^{\mathrm{b}}$ \\
\hline \multicolumn{6}{|l|}{ Thymol } \\
\hline $100 \mathrm{mg} / \mathrm{kg}$ & $0.73 \pm 0.06$ & - & $42306 \pm 2429^{b}$ & $5563 \pm 403.6^{\mathrm{b}}$ & $36742 \pm 2216^{\mathrm{b}}$ \\
\hline $200 \mathrm{mg} / \mathrm{kg}$ & $0.65 \pm 0.03$ & - & $46900 \pm 2931^{b}$ & $6609 \pm 683.8^{b}$ & $40290 \pm 2357^{b}$ \\
\hline $400 \mathrm{mg} / \mathrm{kg}$ & $0.54 \pm 0.05^{\mathrm{a}}$ & 34.2 & $47600 \pm 2987^{b}$ & $6286 \pm 380.3^{\mathrm{b}}$ & $41313 \pm 2979^{b}$ \\
\hline
\end{tabular}

Data are mean \pm SEM of 8-10 animals/group. Indomethacin and celecoxib administered orally were used as reference anti-inflammatory drugs (positive controls). Normal: animals that received injection of saline in the cavity (normal group), Control: animals that received injection of carrageenan in the cavity (negative control). MN: mononuclears cells. PMN: polimorphonuclears cells. ${ }^{a} P<0.05$ compared to control group; ${ }^{b} P<0.05$ compared to normal group (ANOVA, Tukey's test).

by activating T-cells and macrophages that stimulate the release of other inflammatory cytokines. TNF- $\alpha$ is also a mediator of carrageenan-induced inflammation and is able to enhance the further release of kinins and leukotrienes [27]. Nitric oxide has been shown to play an important role in both the regulation of vascular permeability and cell migration induced by proinflammatory agents, including carrageenan $[28,29]$.

The pleurisy model is used to screen anti-inflammatory drugs. Exudate accumulation in the pleural cavity and leukocyte migration can be evaluated [16]. In the pleurisy model, TEO at doses of 250,500 , and $750 \mathrm{mg} / \mathrm{kg}$ significantly reduced inflammatory exudates. At a dose of $750 \mathrm{mg} / \mathrm{kg}$, TEO reduced the number of migrated cells (Table 2). The groups treated with indomethacin and celecoxib exhibited a reduction in inflammatory exudates but not a reduction in leukocyte migration. CVL and thymol significantly reduced the volume of pleural inflammatory exudates by $47.3 \%$ and $34.2 \%$, respectively, at a dose of $400 \mathrm{mg} / \mathrm{kg}$. CVL decreased the number of migrated cells at doses of 100 , 200 , and $400 \mathrm{mg} / \mathrm{kg}$. Thymol, however, was not able to reduce cell migration (Tables 3 and 4). These data indicate that TEO, CVL, and thymol significantly inhibited inflammatory edema, but only TEO and CVL exerted inhibitory effects on leukocyte migration to the injury site. Our data corroborate previous studies that demonstrated the antiinflammatory effects of different essential oils (i.e., inhibition of inflammatory edema and chemotaxis) [30-34]. CVL acts as a suppressor of COX-2 and activator of peroxisome proliferator-activated receptors [35]. Our data suggest that CVL may inhibit prostanoid release because CVL had effects that were similar to indomethacin and celecoxib (i.e., inhibition of COX-1 and -2) [36] (Table 3).

Polymorphonuclear leukocyte recruitment is an essential factor in the acute inflammatory process, acting as first-linedefense cells in the initiation and resolution phases of this 
process [37]. In situations in which uncontrolled infiltration of these cells occurs, they can become the main aggressor factor. Under such conditions, pharmacological interventions with drugs that are able to modulate leukocyte recruitment may present an interesting therapeutic possibility.

The present study also evaluated the effects of thymol and CVL at different concentrations on leukocyte chemotaxis in vitro. The chemoattractants fMLP $\left(10^{-6} \mathrm{M}\right)$ and $\mathrm{LTB}_{4}$ $\left(10^{-8} \mathrm{M}\right)$ were used. CVL at doses of $0.3,1,3,10,30$, and $90 \mu \mathrm{g} / \mathrm{mL}$ significantly reduced $(P<0.05)$ neutrophil migration in response to fMLP stimulation $(20.07 \pm 1.02 \%$, $14.79 \pm 1.79 \%, 25.28 \pm 2.51 \%, 29.48 \pm 2.21 \%, 42.92 \pm$ $2.06 \%$, and $52.23 \pm 1.75 \%$, resp.) and $\mathrm{LTB}_{4}$ stimulation $(19.82 \pm 2.50 \%, 24.81 \pm 1.66 \%, 20.35 \pm 1.18 \%, 30.41 \pm$ $0.61 \%, 36.44 \pm 1.54 \%$, and $61.11 \pm 1.82 \%$, resp.; Figures $2(\mathrm{a})$ and 2(b)). Thymol at doses of $0.3,1,3,10,30$, and $90 \mu \mathrm{g} / \mathrm{mL}$ did not reduce leukocyte migration in vitro in response to $\mathrm{AMLP}$ and $\mathrm{LTB}_{4}$ stimulation (Figures 2(c) and $2(\mathrm{~d}))$. However, thymol at concentrations of $1.5,15$, and $150 \mu \mathrm{g} / \mathrm{mL}$ was a potent chemoattractant agent (Figure 3). CVL and thymol did not affect leukocyte viability at the concentrations tested, suggesting that the direct effects of the treatments on the inhibition of leukocyte chemotaxis did not occur because of the toxic effects that induce cell death.

Only CVL was able to inhibit in vitro chemotaxis induced by fMLP and $\mathrm{LTB}_{4}$, suggesting that CVL and thymol exert their effects on leukocyte chemotaxis through different mechanisms. Leukotriene is a potent chemotactic agent derived from arachidonic acid [38]. fMLP is a chemotactic agent involved in the release of cytokines. Upon binding to its G-protein-coupled receptor, it activates multiple signaling cascade pathways [39]. These pathways include the mitogenactivated protein kinase (MAPK) and phosphatidylinositol 3-kinase (PI-3K) cascades, which are important for the development of the functional responses of neutrophils in inflammation [40, 41]. Our data suggest that CVL may act by inhibiting cytokines and leukotrienes, and these mediators are likely not involved in the mechanism of action of thymol.

To demonstrate the topical effect of thymol and CVL in vivo, we evaluated inflammatory ear edema induced by croton oil. Croton oil is an irritant agent that causes cell damage and activates phospholipase $\mathrm{A}_{2}$, which releases arachidonic acid from the cell plasma membrane. From arachidonic acid, the production of prostaglandins by COX-1 and COX-2 and leukotrienes by 5-lipoxygenase occurs. Prostaglandins and leukotrienes are inflammatory mediators involved in edema and leukocyte migration [42]. Croton oil application to the right ear in mice induced an apparent inflammatory response $4 \mathrm{~h}$ later. An increase in the weight of the ears was observed. Indomethacin $(0.5 \mathrm{mg} / \mathrm{ear})$ and dexamethasone $(0.1 \mathrm{mg} /$ ear $)$ significantly inhibited ear edema by $44 \%$ and $36 \%$, respectively $(P<0.05)$. CVL did not reduce ear edema at concentrations of 20 and $40 \mathrm{mg} / \mathrm{ear}$, but ear edema was reduced at the lowest concentration $(10 \mathrm{mg} /$ ear $)$, similar to the $37.2 \%$ reduction observed with dexamethasone $(P<$ 0.05 ; Figure 4(a)).

The present study showed that CVL at $10 \mathrm{mg} / \mathrm{ear}$ has an antiedematogenic effect when administered topically, similar to the observations with dexamethasone and indomethacin.

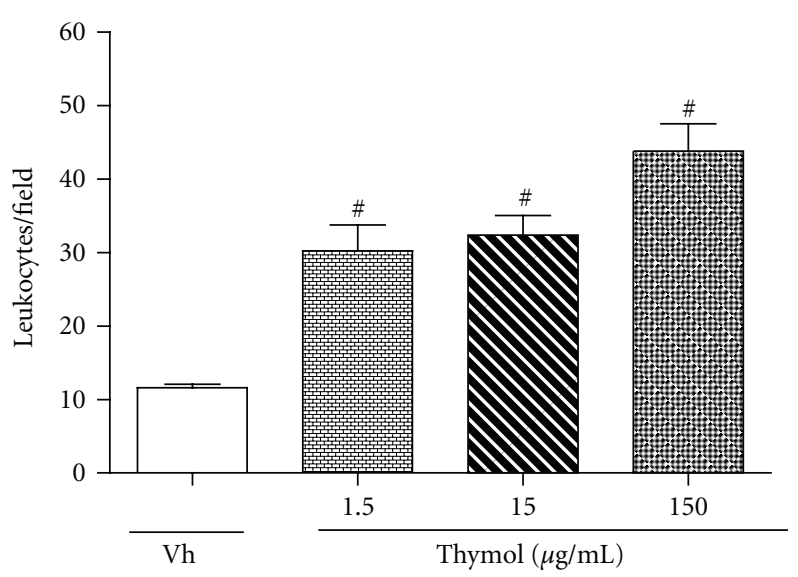

FIgure 3: Thymol used as a chemotactic agent in concentrations of $1.5,15$, and $150 \mu \mathrm{g} / \mathrm{mL}$. Leukocytes were obtained from zymosaninduced peritonitis $(200 \mu \mathrm{g} /$ cavity $)$. Values are mean $\pm \operatorname{SEM}(n=5)$ and are representative of three independent experiments. ${ }^{\#} P<0.05$ versus Vh (vehicle).

In this experimental model, these treatments inhibited both fluid extravasation and cellular influx, indirectly reflected by a reduction in MPO activity. The enzyme MPO is found in the azurophilic granules of neutrophils and other cells of myeloid origin and is considered a marker of polymorphonuclear leukocyte influx into inflamed tissues. Therefore, MPO inhibition may result in an anti-inflammatory effect [23]. CVL (10 mg/ear), indomethacin $(0.5 \mathrm{mg} / \mathrm{ear})$, and dexamethasone $(0.1 \mathrm{mg} /$ ear $)$ significantly inhibited the activity of this enzyme $(43.8 \%, 52.0 \%$, and $38.3 \%$, resp.; $P<0.05$; Figure 4(b)). Our data showed that CVL effectively inhibited chemotaxis in vitro but also had antiedematogenic and antichemotactic effects in vivo (pleurisy test) when administered systemically.

As shown in Figure 5, the ear edema formation intensities were similar between croton oil and thymol, suggesting similar responses to both irritative agents. Ear edema induced by croton oil involves the activation of phospholipase $\mathrm{A}_{2}$ and biosynthesis of prostaglandins and leukotrienes [43, 44]. To compare the probable irritative mechanism of the topical effect of thymol and croton oil, the following experiments were performed. The animals were treated with indomethacin $(5 \mathrm{mg} / \mathrm{kg}$, p.o.) and promethazine $(5 \mathrm{mg} / \mathrm{mL}$, i.p.) $60 \mathrm{~min}$ before the application of thymol. Croton oil was used as a positive control. To evaluate the participation of histamine in this inflammatory response, promethazine was used as an antihistaminic reference drug. Ear edema was determined 30,60,120, 180, and $240 \mathrm{~min}$ after the inflammatory stimulation. The time-course analysis of thymol revealed an increase in edema volume at $60 \mathrm{~min}$ (Figure 6). This response could be attributable to the release of different autacoids, including histamine. Essential oils and their isolated compounds can promote the release of histamine and other mediators, acting as irritative agents [45]. Indomethacin treatment effectively reduced the formation of ear edema induced by thymol, whereas promethazine 


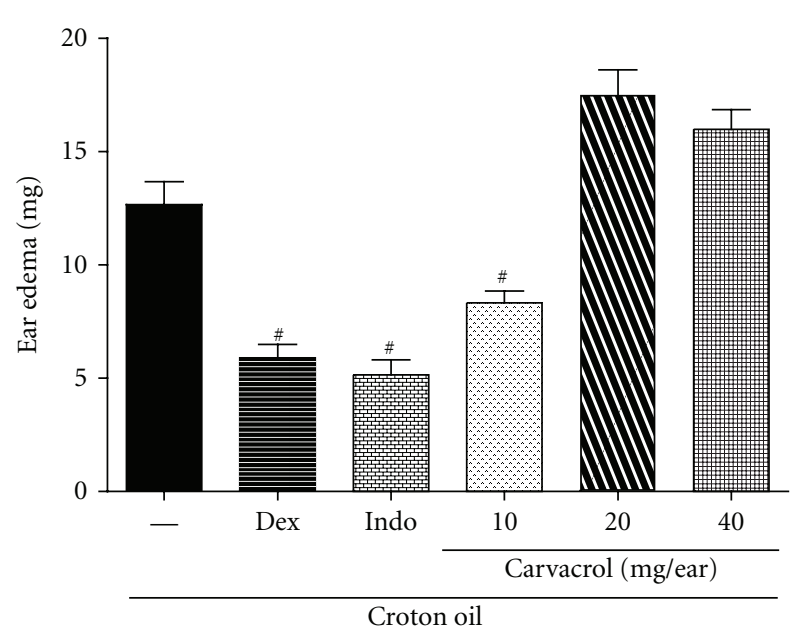

(a)

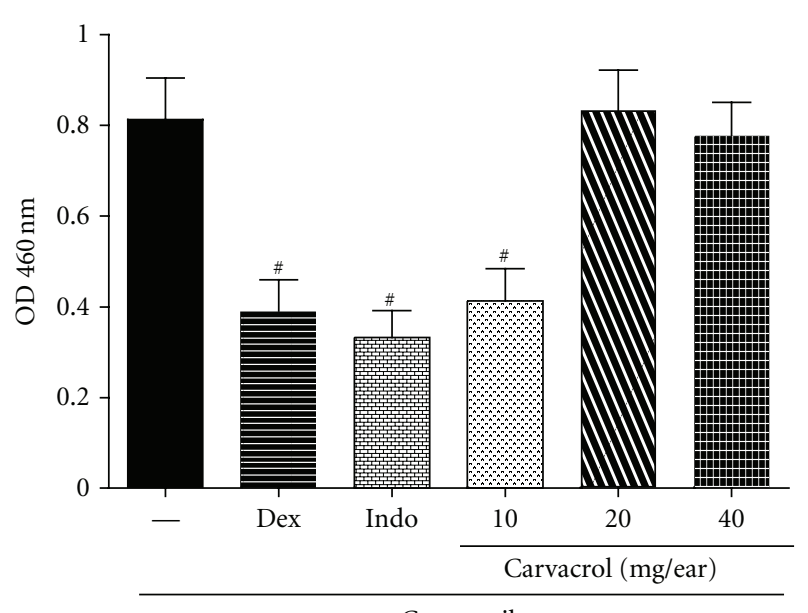

Croton oil

(b)

Figure 4: Effect of CVL on ear edema (a) and myeloperoxidase activity (MPO) (b) induced by croton oil in ear tissues from mice. The animals $(n=9)$ were treated topically with carvacrol, indomethacin (Indo), or dexamethasone (Dex) $1 \mathrm{~h}$ before croton oil application (10 $\mu \mathrm{L} /$ ear). Dex ( $0.1 \mathrm{mg} /$ ear) or Indo $(0.5 \mathrm{mg} /$ ear $)$ were used as anti-inflammatory drugs (positive control). The right ears received only the vehicle (Basal). Data are mean \pm SEM weight of the ears (a) or MPO activity (b), 4 hours after application of croton oil, ${ }^{\#} P<0.05$, compared to the control group (croton oil) (ANOVA, Tukey's test).

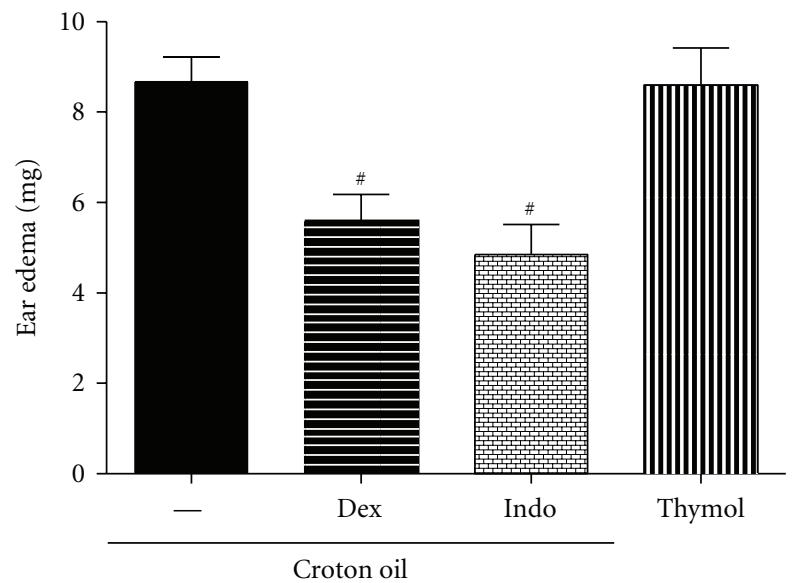

(a)

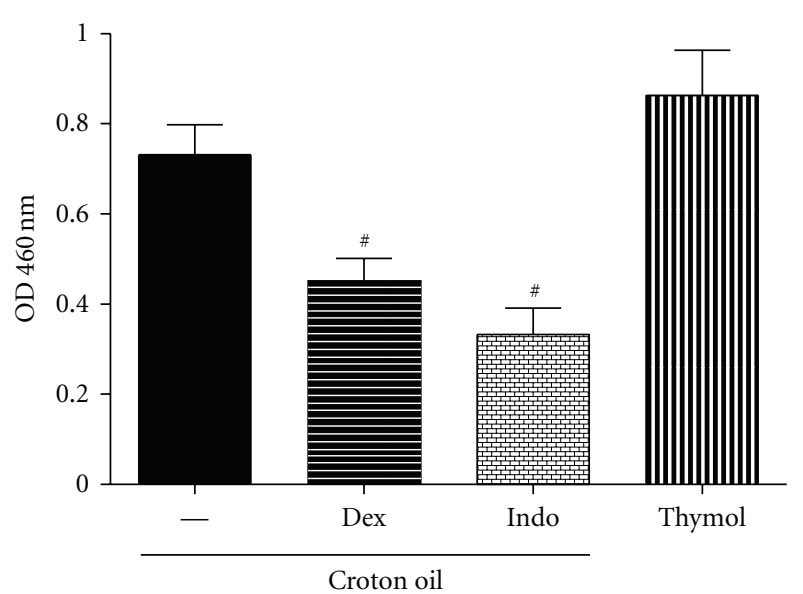

(b)

FIGURE 5: Effect of thymol on ear edema (a) and myeloperoxidase activity (MPO) (b) in ear tissues from mice. The animals $(n=9)$ were treated topically with indomethacin (Indo) or dexamethasone (Dex) $1 \mathrm{~h}$ before croton oil application $(10 \mu \mathrm{L} /$ ear). The group treated with thymol did not received the croton oil. Dex $(0.1 \mathrm{mg} /$ ear $)$ and Indo $(0.5 \mathrm{mg} /$ ear) were used as anti-inflammatory drugs (positive control). The right ears received only the vehicle. Data are mean \pm SEM weight of the ears (a) or MPO activity (b), 4 hours after application of croton oil or thymol. ${ }^{*} P<0.05$, compared to the control group (croton oil) (ANOVA, Tukey's test).

treatment only inhibited the early stage of edema. Our results indicate that the edematogenic response of thymol is partially dependent on histamine and prostanoids. Therefore, our results suggest that thymol has an irritative effect, similar to the effect observed with croton oil.

Thus, our results are consistent with the literature and showed that TEO has anti-inflammatory effects in vivo. However, the isolated compounds thymol and CVL showed antagonist effects. Thymol has an irritative effect that likely involves histamine, prostanoids, and other inflammatory mediators. CVL may be the compound responsible for the anti-inflammatory effects of TEO, demonstrated by chemotaxis in vitro. The present study contributes to the growing evidence of the anti-inflammatory effects of natural products. Overall, our data support the hypothesis that the inhibitory effect of CVL on leukocyte migration contributes to its anti-inflammatory action, in addition to the irritant effect of thymol. 


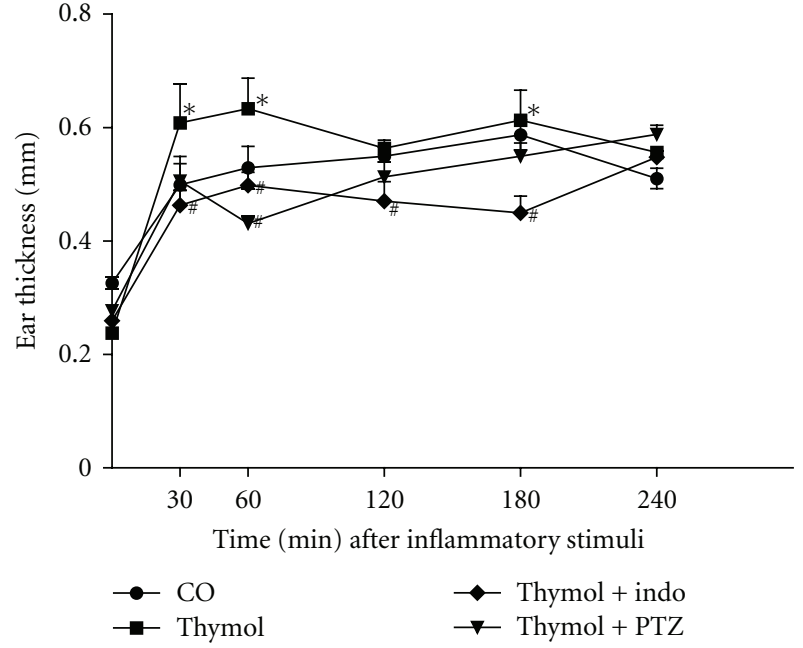

Figure 6: Ear edema induced by thymol (10 mg/ear). The animals $(n=8)$ were treated with indomethacin (Indo) $(5 \mathrm{mg} / \mathrm{Kg}$, v.o.) or promethazine (PTZ) (5 mg/Kg, i.p.) 60 minutes beforethe thymol application. The croton oil (CO) was used for positive control. The ear edema was determined in 30, 60, 120, 180, and 240 minutes after inflammatory stimuli. Data are mean \pm SEM of the ear thickness, ${ }^{\#} P<0.05$ compared to thymol group. ${ }^{*} P<0.05$ compared to the positive control (ANOVA, Tukey's test).

\section{Conflict of Interests}

The authors declare that they have no conflict of interests.

\section{Acknowledgments}

This study was supported by grants from CAPES (Coordenadoria de Aperfeiçoamento de Pessoal de Nível Superior) and $\mathrm{CNPq}$ (Conselho Nacional de Desenvolvimento Científico e Tecnológico), Brazil. The authors thank Mr. Jailson Araujo Dantas and Mrs. Celia Regina Miranda for technical assistance.

\section{References}

[1] A. Zarzuelo and E. Crespo, "The medicinal and non-medicinal uses of thyme," in Thyme: The Genus Thymus. Medicinal and Aromatic Plants-Industrial Profiles, E. Stahl-Biskup and F. Saez, Eds., pp. 263-292, Taylor \& Francis, New York, NY, USA, 2002.

[2] K. M. Soliman and R. I. Badeaa, "Effect of oil extracted from some medicinal plants on different mycotoxigenic fungi," Food and Chemical Toxicology, vol. 40, no. 11, pp. 1669-1675, 2002.

[3] A. Rustaiyan, S. Masoudi, A. Monfared et al., "Volatile constituents of three Thymus species grown wild in Iran," Planta Medica, vol. 66, no. 2, pp. 197-198, 2000.

[4] H. Amiri, "Essential oils composition and antioxidant properties of three Thymus species," Evidence-Based Complementary and Alternative Medicine, vol. 2012, Article ID 728065, 2012.

[5] B. Nickavar, F. Mojab, and R. Dolat-Abadi, "Analysis of the essential oils of two Thymus species from Iran," Food Chemistry, vol. 90, no. 4, pp. 609-611, 2005.

[6] M. Höferl, G. Buchbauer, L. Jirovetz et al., "Correlation of antimicrobial activities of various essential oils and their main aromatic volatile constituents," Journal of Essential Oil Research, vol. 21, no. 5, pp. 459-463, 2009.

[7] K. A. Youdim, H. J. Damien Dorman, and S. G. Deans, "The antioxidant effectiveness of thyme oil, $\alpha$-tocopherol and ascorbyl palmitate on evening primrose oil oxidation," Journal of Essential Oil Research, vol. 11, no. 5, pp. 643-648, 1999.

[8] J. Barnes, L. A. Anderson, and J. D. Philipson, Herbal Medicines, Pharmaceutical Press, London, UK, 3rd edition, 2007.

[9] H. J. D. Dorman and S. G. Deans, "Antimicrobial agents from plants: antibacterial activity of plant volatile oils," Journal of Applied Microbiology, vol. 88, no. 2, pp. 308-316, 2000.

[10] ESCOP, ESCOP Monographs: The Scientific Foundation for Herbal Medicinal Products, The European Scientific Cooperative on Phytotherapy in collaboration with Georg Thieme, 2nd edition, 2007.

[11] R. Vila, "Flavonoids and further polyphenols in the genus Thymus," in Thyme: The Genus Thymus. Medicinal and Aromatic Plants_Industrial Profiles, E. Stahl-Biskup and F. Saez, Eds., p. 75, Taylor and Francis, New York, NY, USA, 2002.

[12] A. A. El-Nekeety, S. R. Mohamed, A. S. Hathout, N. S. Hassan, S. E. Aly, and M. A. Abdel-Wahhab, "Antioxidant properties of Thymus vulgaris oil against aflatoxin-induce oxidative stress in male rats," Toxicon, vol. 57, no. 7-8, pp. 984-991, 2011.

[13] S. Asbaghian, A. Shafaghat, K. Zarea, F. Kasimov, and F. Salimi, "Comparison of volatile constituents, and antioxidant and antibacterial activities of the essential oils of Thymus caucasicus, T. kotschyanus and T. vulgaris," Natural Product Communications, vol. 6, no. 1, pp. 137-140, 2011.

[14] R. P. Adams, Identification of Essential Oil Components by Gas Chromatography/Mass Spectroscopy, Allured Publishing Corporation, Carol Stream, Ill, USA, 4th edition, 2007.

[15] D. Lorke, "A new approach to practical acute toxicity testing," Archives of Toxicology, vol. 54, no. 4, pp. 275-287, 1983.

[16] R. Vinegar, J. F. Truax, and J. L. Selph, "Some quantitative temporal characteristics of carrageenin induced pleurisy in the rat," Proceedings of the Society for Experimental Biology and Medicine, vol. 143, no. 3, pp. 711-714, 1973.

[17] P. P. Bradley, D. A. Priebat, R. D. Christensen, and G. Rothstein, "Measurement of cutaneous inflammation: estimation of neutrophil content with an enzyme marker," Journal of Investigative Dermatology, vol. 78, no. 3, pp. 206-209, 1982.

[18] A. Aderem and R. J. Ulevitch, "Toll-like receptors in the induction of the innate immune response," Nature, vol. 406, no. 6797, pp. 782-787, 2000.

[19] F. Nantel, D. Denis, R. Gordon et al., "Distribution and regulation of cyclooxygenase-2 in carrageenan-induced inflammation," British Journal of Pharmacology, vol. 128, no. 4, pp. 853-859, 1999.

[20] C. Bogdan, "Nitric oxide and the immune response," Nature Immunology, vol. 2, no. 10, pp. 907-916, 2001.

[21] M. Batlouni, "Nonsteroidal anti-inflammatory drugs: cardiovascular, cerebrovascular and renal effects," Arquivos Brasileiros de Cardiologia, vol. 94, no. 4, pp. 522-563, 2010.

[22] P. Crunkhorn and S. C. Meacock, "Mediators of the inflammation induced in the rat paw by carrageenin," British Journal of Pharmacology, vol. 42, no. 3, pp. 392-402, 1971.

[23] C. J. Niemegeers, F. J. Verbruggen, and P. A. Janssen, "Effect of various drugs on carrageenan-induced oedema in the rat hind paw," Journal of Pharmacy and Pharmacology, vol. 16, pp. 810-816, 1964.

[24] B. H. Havsteen, "The biochemistry and medical significance of the flavonoids," Pharmacology and Therapeutics, vol. 96, no. 2-3, pp. 67-202, 2002. 
[25] S. H. Lee, E. Soyoola, P. Chanmugam et al., "Selective expression of mitogen-inducible cyclooxygenase in macrophages stimulated with lipopolysaccharide," Journal of Biological Chemistry, vol. 267, no. 36, pp. 25934-25938, 1992.

[26] A. K. Nussler and T. R. Billiar, "Inflammation, immunoregulation, and inducible nitric oxide synthase," Journal of Leukocyte Biology, vol. 54, no. 2, pp. 171-178, 1993.

[27] C. R. Tonussi and S. H. Ferreira, "Tumour necrosis factor- $\alpha$ mediates carrageenin-induced knee-joint incapacitation and also triggers overt nociception in previously inflamed rat knee-joints," Pain, vol. 82, no. 1, pp. 81-87, 1999.

[28] H. O. Collier, L. C. Dinneen, C. A. Johnson, and C. Schneider, "The abdominal constriction response and its suppression by analgesic drugs in the mouse," British Journal of Pharmacology, vol. 32, no. 2, pp. 295-310, 1968.

[29] S. H. Ferreira and J. R. Vane, "New aspects of mode of action of non-steroid anti-inflammatory drugs," Annual Review of Pharmacology, vol. 14, pp. 57-73, 1974.

[30] A. C. Siani, M. F. S. Ramos, O. Menezes-de-Lima Jr. et al., "Evaluation of anti-inflammatory-related activity of essential oils from the leaves and resin of species of Protium," Journal of Ethnopharmacology, vol. 66, no. 1, pp. 57-69, 1999.

[31] A. Vendruscolo, I. Takaki, L. E. Bersani-Amado, J. A. Dantas, C. A. Bersani-Amado, and R. K. N. Cuman, "Antiinflammatory and antinociceptive activities of zingiber officinale roscoe essential oil in experimental animal models," Indian Journal of Pharmacology, vol. 38, no. 1, pp. 58-59, 2006.

[32] I. Takaki, L. E. Bersani-Amado, A. Vendruscolo et al., "Antiinflammatory and antinociceptive effects of Rosmarinus officinalis L. essential oil in experimental animal models," Journal of Medicinal Food, vol. 11, no. 4, pp. 741-746, 2008.

[33] G. A. Nogueira de Melo, R. Grespan, J. P. Fonseca et al., "Rosmarinus officinalis L. essential oil inhibits in vivo and in vitro leukocyte migration," Journal of Natural Medicines, vol. 14, pp. 944-946, 2011.

[34] G. A. Nogueira de Melo, R. Grespan, J. P. Fonseca et al., "Inhibitory effects of ginger (Zingiber officinale Roscoe) essential oil on leukocyte migration in vivo and in vitro," Journal of Natural Medicines, vol. 65, no. 1, pp. 241-246, 2011.

[35] M. Hotta, R. Nakata, M. Katsukawa, K. Hori, S. Takahashi, and $\mathrm{H}$. Inoue, "Carvacrol, a component of thyme oil, activates $\operatorname{PPAR} \alpha$ and $\gamma$ and suppresses COX-2 expression," Journal of Lipid Research, vol. 51, no. 1, pp. 132-139, 2010.

[36] J. R. Vane, "Inhibition of prostaglandin synthesis as a mechanism of action for aspirin-like drugs," Nature, vol. 231, no. 25, pp. 232-235, 1971.

[37] C. N. Serhan, "Resolution phase of inflammation: novel endogenous anti-inflammatory and proresolving lipid mediators and pathways," Annual Review of Immunology, vol. 25, pp. 101-137, 2007.

[38] B. Samuelsson, S. E. Dahlen, and J. A. Lindgren, "Leukotrienes and lipoxins: structures, biosynthesis, and biological effects," Science, vol. 237, no. 4819, pp. 1171-1176, 1987.

[39] B. Haribabu, R. M. Richardson, M. W. Verghese, A. J. Barr, D. V. Zhelev, and R. Snyderman, "Function and regulation of chemoattractant receptors," Immunologic Research, vol. 22, no. 2-3, pp. 271-279, 2000.

[40] A. Mócsai, Z. Jakus, T. Vántus, G. Berton, C. A. Lowell, and E. Ligeti, "Kinase pathways in chemoattractant-induced degranulation of neutrophils: the role of p38 mitogenactivated protein kinase activated by Src family kinases," Journal of Immunology, vol. 164, no. 8, pp. 4321-4331, 2000.
[41] P. J. Coffer, N. Geijsen, L. M'Rabet et al., "Comparison of the roles of mitogen-activated protein kinase kinase and phosphatidylinositol 3-kinase signal transduction in neutrophil effector function," Biochemical Journal, vol. 329, no. 1, pp. 121-130, 1998.

[42] L. Kremmyda, E. Tvrzicka, B. Stankova, and A. Zak, "Fatty acids as biocompounds: their role in human metabolism, helth and disesse - a review. Part 2: fatty acid physiological roles and applications in human health and disese," Biomedical Papers of the Medical Faculty of the University Palacky, Olomouc, Czech Republic, vol. 155, no. 3, pp. 195-218, 2011.

[43] H. Kondoh, Y. Sato, and H. Kanoh, "Arachidonic acid metabolism in cultured mouse keratinocytes," Journal of Investigative Dermatology, vol. 85, no. 1, pp. 64-69, 1985.

[44] G. Fuerstenberger and F. Marks, "Early prostaglandin E synthesis is an obligatory event in the induction of cell proliferation in mouse epidermis in vivo by the phorbol ester TPA," Biochemical and Biophysical Research Communications, vol. 92, no. 3, pp. 749-756, 1980.

[45] E. S. Fernandes, G. F. Passos, R. Medeiros et al., "Antiinflammatory effects of compounds alpha-humulene and (-)trans-caryophyllene isolated from the essential oil of Cordia verbenacea," European Journal of Pharmacology, vol. 569, no. 3, pp. 228-236, 2007. 


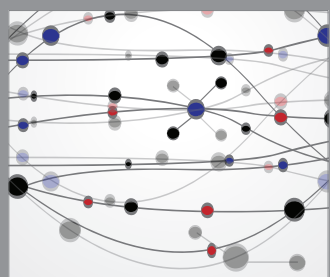

The Scientific World Journal
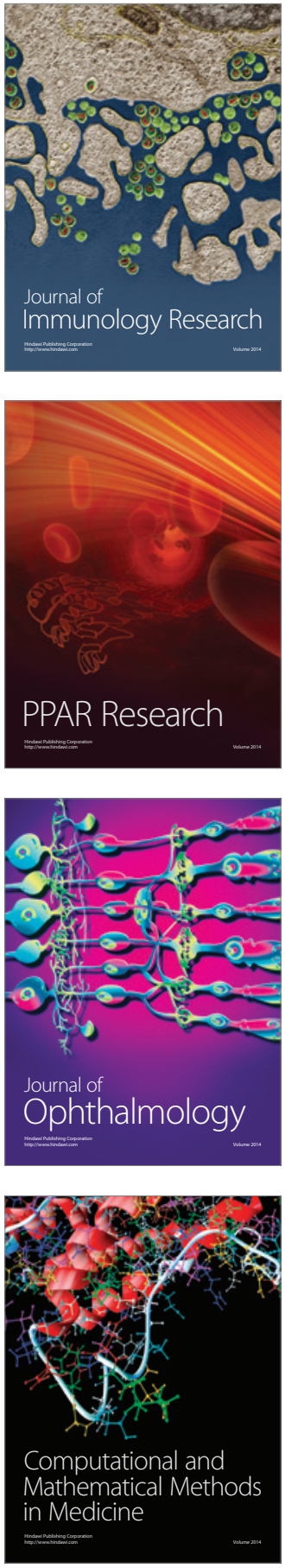

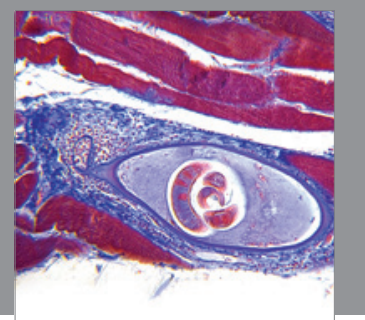

Gastroenterology

Research and Practice
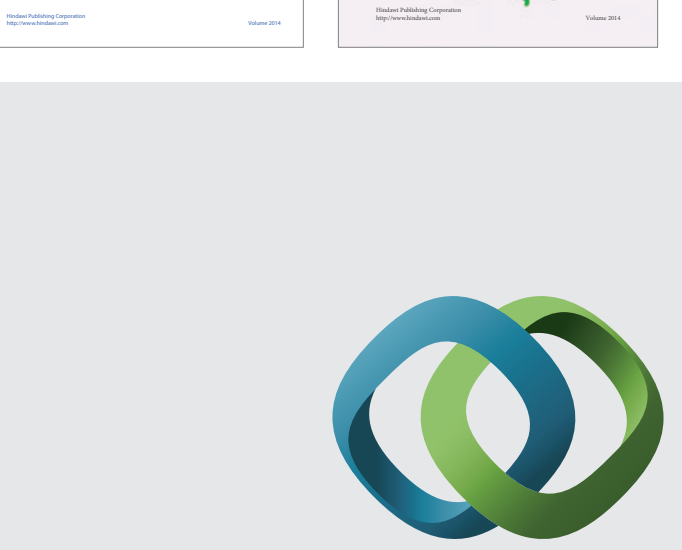

\section{Hindawi}

Submit your manuscripts at

http://www.hindawi.com
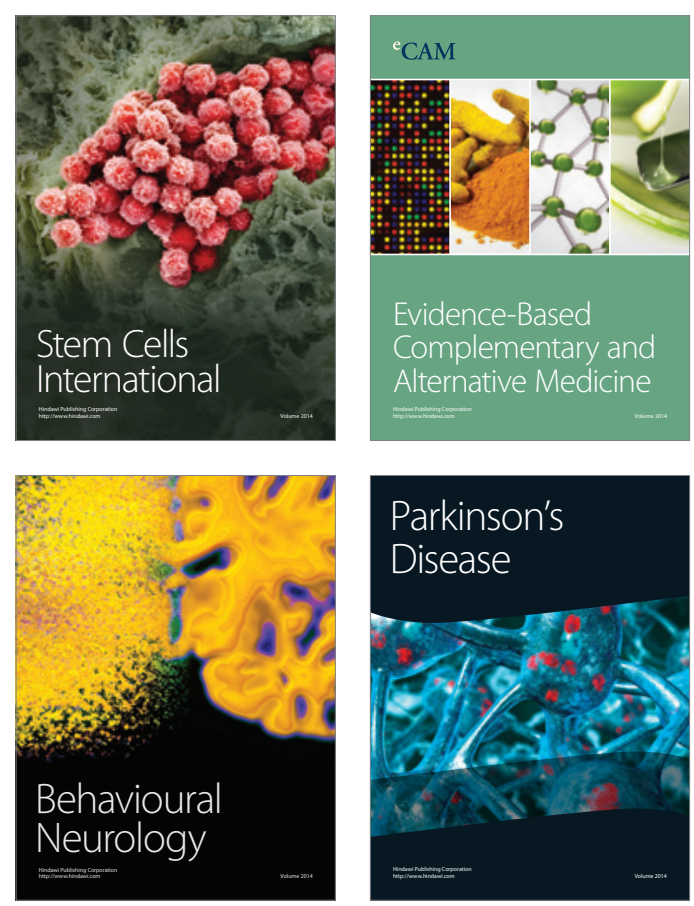

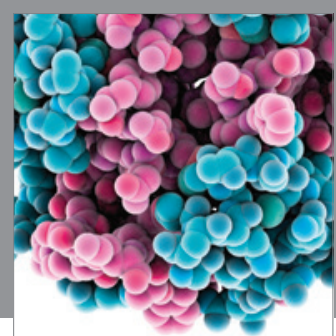

Journal of
Diabetes Research

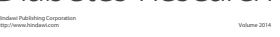

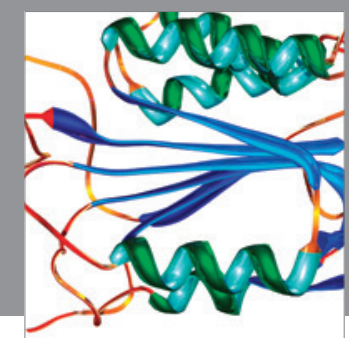

Disease Markers
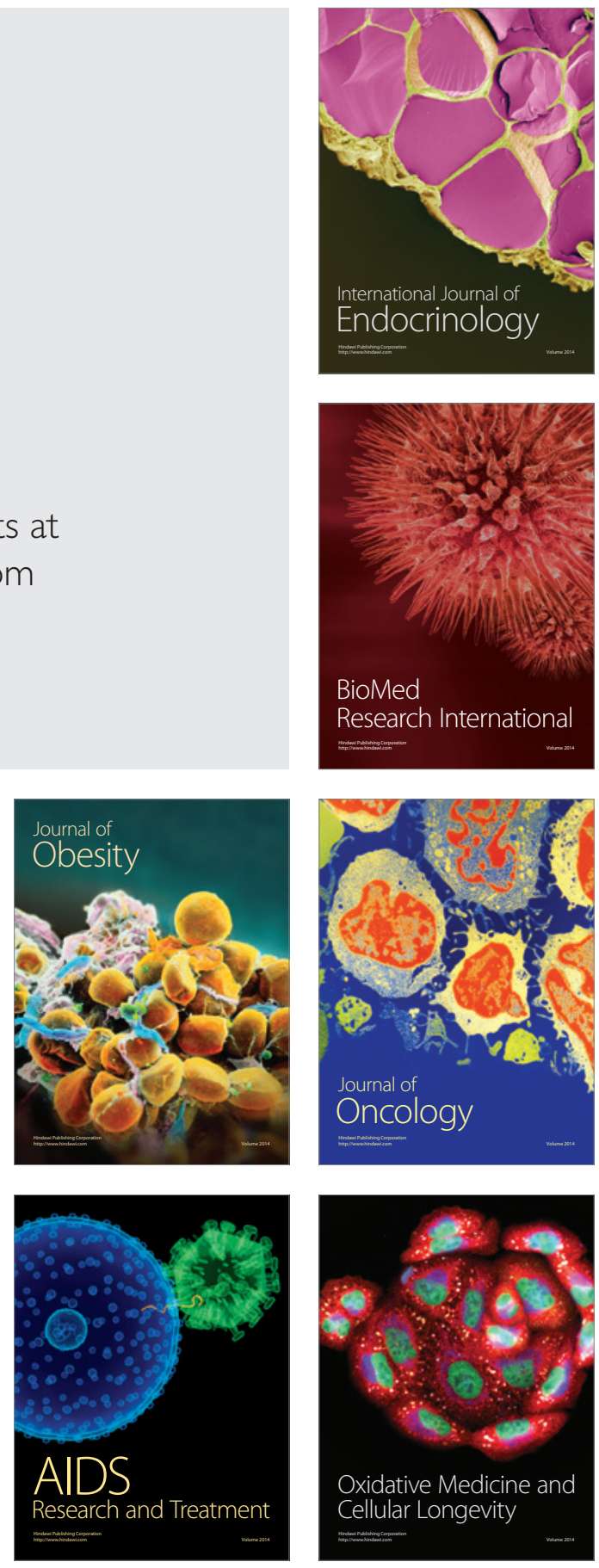